\title{
Challenges Related to Rituals and Law Facing Saudi Students in the UK
}

\author{
Tareq Albhlal $^{1} \&$ Hajed A. Alotaibi ${ }^{2}$ \\ ${ }^{1}$ Department of Contemporary Islamic Studies, Faculty of Science and Humanities at Rumah, Majmaa \\ University, Riyadh, Saudi Arabia \\ ${ }^{2}$ Department of Contemporary Islamic Studies, Faculty of Science and Humanities at Hawtat Sudair, Majmaa \\ University, Riyadh, Saudi Arabia \\ Correspondence: Hajed A. Alotaibi, Department of Contemporary Islamic Studies, Faculty of Science and \\ Humanities at Hawtat Sudair, Majmaa University, 11952, Riyadh, Saudi Arabia. Tel: 966-5-8002-8990. E-mail: \\ h.alotaibi@mu.edu.sa
}

Received: February 8, 2020

Accepted: March 26, $2020 \quad$ Online Published: March 28, 2020

doi:10.5539/jpl.v13n2p11

URL: https://doi.org/10.5539/jpl.v13n2p11

\begin{abstract}
Saudi students studying abroad encounter some challenges as regards the climate and culture of the UK. These challenges may not only be observed in the language and academic curriculum. Hence, this study aims to test the rooted religious values and jurisdiction practices among Saudi Muslims concerning their experiences, needs and other challenges while studying in the UK. This study included a sample of 100 Saudi students enrolled in a different academic year in the UK institutes. Findings reveal that the majority of the Middle Eastern students experienced difficulties in offering prayers, displaying Islamic rituals such as funerals, and paying Zakat to people. These students also experienced problems in learning about juristic and judicial regulations and identifying the significance of civil and human rights, intellectual/religious tolerance, and women's rights. Most of the students experienced issues with their wives due to the social environment. Understanding this experience is significant to help ease the students' challenges and make their experience in the UK successful.
\end{abstract}

Keywords: juristic challenges, cultural issues, UK universities, Saudi students

\section{Introduction}

Globalization promotes individuals to reflect and respect cultural diversity and cross border relations. This has also encouraged mobilization among Muslim students who move abroad to pursue higher education (Wu, Garza, \& Guzman, 2015). In the context of the United Kingdom (UK), an increased inflow of international students is observed, which was 4.13 million in 2016 and is expected to increase by 17.2 percent until 2050 (Statista, 2016). Generally, the majority of the Muslim population in these institutes comes from the Arab regions.

The transition to these countries is challenging for the students due to their cultural, religious as well as jurisdictional differences (Yakaboski, Perez-Velez, \& Almutairi, 2016). Also, the substantial number of Muslim students in the European countries raises significant concerns about their protection and rights given the fact that sentiments against Islamophobia in these countries have substantially grown. Though efforts are made to reduce the fear related to Islam, similar efforts are combating the immigration of students from Islamic countries (Powell, 2018). Despite the persistence of the negative perception towards it (Gallup, Inc., 2015) and the rise of hate crime in the UK (Statista, 2019), the enrollments of the Muslim students continues to increase throughout the United Kingdom (UK International Students Affair Council, 2018). Recent studies have reasoned that this is due to the increase in government-funded scholarships (Perna et al., 2014; Yakaboski, Perez-Velez, \& Almutairi, 2016). Considering the rising population of the UK international students as well as the added benefits of the international education such as better economic status, academic, and social position (Institute of Higher Education, 2017; UNESCO, 2016; NAFSA, 2017), there is an increase in Saudi students who are moving abroad.

This information is further stimulated by the provided government support. For instance, Saudi government funds about 2 billion dollars annually to facilitate the achievement of its set Saudi Vision 2030 objective, which necessitates its academic stance parallel to the international standard (Alshuwaikhat, \& Mohammed, 2017). In 
addition, the experience of these students helps in understanding the intensity of different social and academic challenges that students have to endure. Although, various researches have explored the transfer of Muslim students to the higher education, these are typically concentrated on the cultural adjustment of a specific gender or both (Dinning et al., 2016; Anderson, Wason, \& Southall, 2016) or that of US institutes (Mesidor, \& Sly, 2016; Chao, Takeuchi, \& Farh, 2017). Very few researches have explored the Muslim students' experience in the UK, specifically during a period of increased Islamophobia, with augmented incidents of hate crimes against the Muslims. This study is centered on the shared religious and cultural ties which impact the Muslims during their effort to meet their academic and social needs and improve their learning experience in the UK.

Muslim students studying abroad encounter various difficulties concerning socio-cultural life in the UK. These challenges may not be addressed in the language and academic curriculum. The difference in the cultural background, language, and climate can lead to an abrupt and uncomfortable experience for the students. Lefdahl-Davis \& Perrone-McGovern (2015) support this claim in the context of Saudi international students where challenges include communication barriers, financial stress, religious practices, housing, jurisdiction, and cultural differences. Lack of English-speaking proficiency impedes the social interactions of international students, contributing to their academic difficulties (Alsabatin, 2015).

Smith \& Silva's (2011) study indicates ethnic identity as the major difference between the cultures of the two regions, expressed in the form of increased commitment and duty. The inclusion of the Saudi students among the international body of students at UK institutes further becomes intensifies considering the language barrier (Alhazmi 2010; Heyn 2013). For example, the Arabic script is one from right to left whereas it is the opposite for English, i.e. left to right (Saigh \& Schmitt 2012). Related research by Alqarni (2018) indicates the varying experience of Saudi international students where difficulty related to the acquaintance and friendship have been found. It highlighted that Muslim students find it much easier to develop a friendship with "non-Caucasian" students. Students can have different perceptions of how religion and science associate because there are contradictions in opinions on the natures of religion and science. Students can extend their knowledge and awareness of the concepts of religion and science and also of the conflict involved when striving to distinguish barriers and associations between them (Billingsley et al., 2016).

Ali et al. (2017) illuminate the difficulty of the students related to their balancing of the spiritual and academic needs. For instance, a student may have to appear for an exam, on his religious celebratory event of Eid, while his home country observes a public holiday. Stevenson et al. (2017) describe that the practices related to the pervasiveness related to Islamic phobia remain unchecked. Simbar (2008) also reports that the difference in Islamic law is a major challenge observed across the western states. It exemplifies that secularism segregates religion from societal and state matters concentrating it to the personal sphere and worship places. Contrary to it, Islam provides a guideline that relates to every aspect of life, necessitating the believers to commit to its all teachings. Ali (2008) states that the difference in the law further hinders the Saudi students' acceptance of western practices, which affect their experience at an institute. Considering the difference of cultural, religious, and jurisdiction among the two regions, the study aims to assess the Saudi students' experience concerning their integration challenges, and the ways these can be mitigated or overcome.

The research is significant as it sheds light on the international events, for example, the incident of 7 July 2005 in London and the recent Manchester Arena bombing on May 2017 (McKenna, \& Francis, 2018). This presents the experience of the Muslims in the recent events and the challenges they have to endure as international Muslim students. The study focuses on the religious and judicial profile of the students which have been researched by very few studies and mostly in the context of the US (Alsabatin, 2015; Macias, 2016; Powell, 2018). It focusses on religious self-assessment, conversation, and related jurisdiction law. It provides a unique perspective on the experience of Saudi international students and emphasizes the significant concerns and provides a guideline for future research. Additionally, it also contributes by highlighting the efforts which are adopted in Manchester for combating the hateful radicalization. Therefore, the study aims to test the rooted religious values and jurisdiction practices among the Saudi Muslim students' experiences, their needs along with the challenges that they experience while studying in the UK.

The increasing economic growth may result in contradictions between available jobs and worker skills. Disparities between working conditions and salary expectations versus their reality might be a potential source of discontent among international students. This is unlikely that these contradictions will be resolved within the next decade, whereas current education reforms will assist in improving the situation. Generally, the Arabian Gulf region is one of the fastest-growing populations worldwide. By 2020, it is anticipated that this population will increase by one-third to around 53 million individuals. The majority of this population would be young. This presents significant challenges for all Gulf governments, such as Saudi Arabia, even though the increasing 
growth and expansion are directed towards the youth population and its major changes. The accessibility to education, new digital/online technologies, and international media influence the social attitudes, norms, and identity of young Saudis. The overseas scholarship program of Saudis could result in students returning with new thoughts, behaviors, and ideas that may contradict current Islamic and cultural practices.

\section{Methodology}

\subsection{Study Design}

This study used a correlational study design for assessing religious and juristic challenges facing Saudi Students in the UK. This research design is selected as it helps in numerically assessing the subject matter as well as its effectiveness and efficiency for collecting data (Creswell, 2013). This numerical representation makes it easy for the reader to comprehend the results.

\subsection{Population and Sample}

Through simple random sampling, the study selected 100 individuals who were enrolled in the UK. This sample was derived from a research population of Saudi students enrolled in different years in their institutes. The population was associated with the Institute for 1 year or more e.g. 4 years.

\subsection{Data Collection}

This study used a close-ended questionnaire-based survey, which allows the effective and efficient gathering of data. The questionnaire is divided into four sections, where the first section collects demographic details of the participants, and the second section is centered on the religious difficulties, the third section deals with juristic challenges while the fourth section explores social intellectual and cultural aspects. The questionnaire will further be based on a 3-point Likert scale (from 1 agree to 3 disagree).

\subsection{Validity and Reliability}

Before the distribution of the questionnaire, it was assessed for its reliability and validity. The reliability of questionnaire items was assessed using Cronbach's Alpha, whereas for ascertaining the research validity, it was viewed by the experts in the social science curriculum. For ascertaining the research validity for its language, significance, clarity (as it was originally prepared in Arabic), it was sent to professionals in the discipline of instructional design and educational psychology. The items of the questionnaire were amended, edited, and altered as per the experts' feedback.

\subsection{Data Analysis}

For assessing the collected data, IBM Statistical Package for Social Sciences (SPSS) version 21 was used. The demographics of the students were represented in the form of frequencies and percentages. The responses for the other two sections were assessed categorically using Chi-square in the form of the contingency table. The results demonstrate the responses that reach statistical significance value of $(\mathrm{p}<0.05)$.

\section{Results}

The demographic profile of participants including gender, age, stage of the study, marital status, career type, and scholarship status is presented in Table $1.86 .0 \%$ of the male participants and $14.0 \%$ of the female participants were included in this study. $11.0 \%$ and $22.0 \%$ of participants were having ages between $22-25$ years and $26-29$ years, respectively. $8.0 \%$ of the students were enrolled in a Bachelor program, followed by a Master's program (41.0\%), Ph.D. program (37.0\%), and language (11.0\%). $81.60 \%$ of the students were employed in the government sector, followed by $14 \%$ of the students in the private sector. $78.0 \%$ of the students were married, while $22.0 \%$ of the students were bachelor. $92.0 \%$ of the students were sponsored while $2.0 \%$ of the students studying in the UK universities were on the grant. 
Table 1. Demographic characteristics

\begin{tabular}{|c|c|c|c|}
\hline Variables & & Frequency & Percent \\
\hline \multicolumn{4}{|l|}{ Gender } \\
\hline & Male & 86 & 86.0 \\
\hline & Female & 14 & 14.0 \\
\hline \multicolumn{4}{|l|}{ Age } \\
\hline & $18-21$ years & - & - \\
\hline & $22-25$ years & 11 & 11.0 \\
\hline & $26-29$ years & 22 & 22.0 \\
\hline & More than 30 years & 67 & 67.0 \\
\hline \multicolumn{4}{|c|}{ Stage of Study } \\
\hline & Language & 11 & 11.0 \\
\hline & Foundation & 1 & 1.0 \\
\hline & Bachelor & 8 & 8.0 \\
\hline & Masters & 41 & 37.0 \\
\hline & $\mathrm{PhD}$ & 37 & 37.0 \\
\hline & Training & 2 & 2.0 \\
\hline \multicolumn{4}{|c|}{ Career Type } \\
\hline & Government & 81 & 81.0 \\
\hline & Private Sector & 14 & 14.0 \\
\hline & Businessman & 3 & 3.0 \\
\hline & Permanent stay & 2 & 2.0 \\
\hline & Refugee & - & - \\
\hline \multicolumn{4}{|c|}{ Marital Status } \\
\hline & Married & 78 & 78.0 \\
\hline & Bachelor & 22 & 22.0 \\
\hline \multicolumn{4}{|c|}{ Scholarship status } \\
\hline & Sponsored & 92 & 92.0 \\
\hline & Self-funded & 6 & 6.0 \\
\hline & Grant & 2 & 2.0 \\
\hline
\end{tabular}

The following table is designed to show the religious difficulties experienced by Saudi students in the UK. One of the major difficulties experienced by students was to perform prayers as $55.8 \%$ of the male students and $42.9 \%$ of the female students claimed that it is not easy performing prayers whenever and wherever. $58.1 \%$ of male students cannot display Islamic rituals such as funerals and prayers. $54.7 \%$ of male students cannot easily fast in the UK despite the weather and long days. $34.9 \%$ of the male students and $57.1 \%$ of the female students cannot easily pay Zakat to people in the UK (Table 2). 
Table 2. Religious difficulties

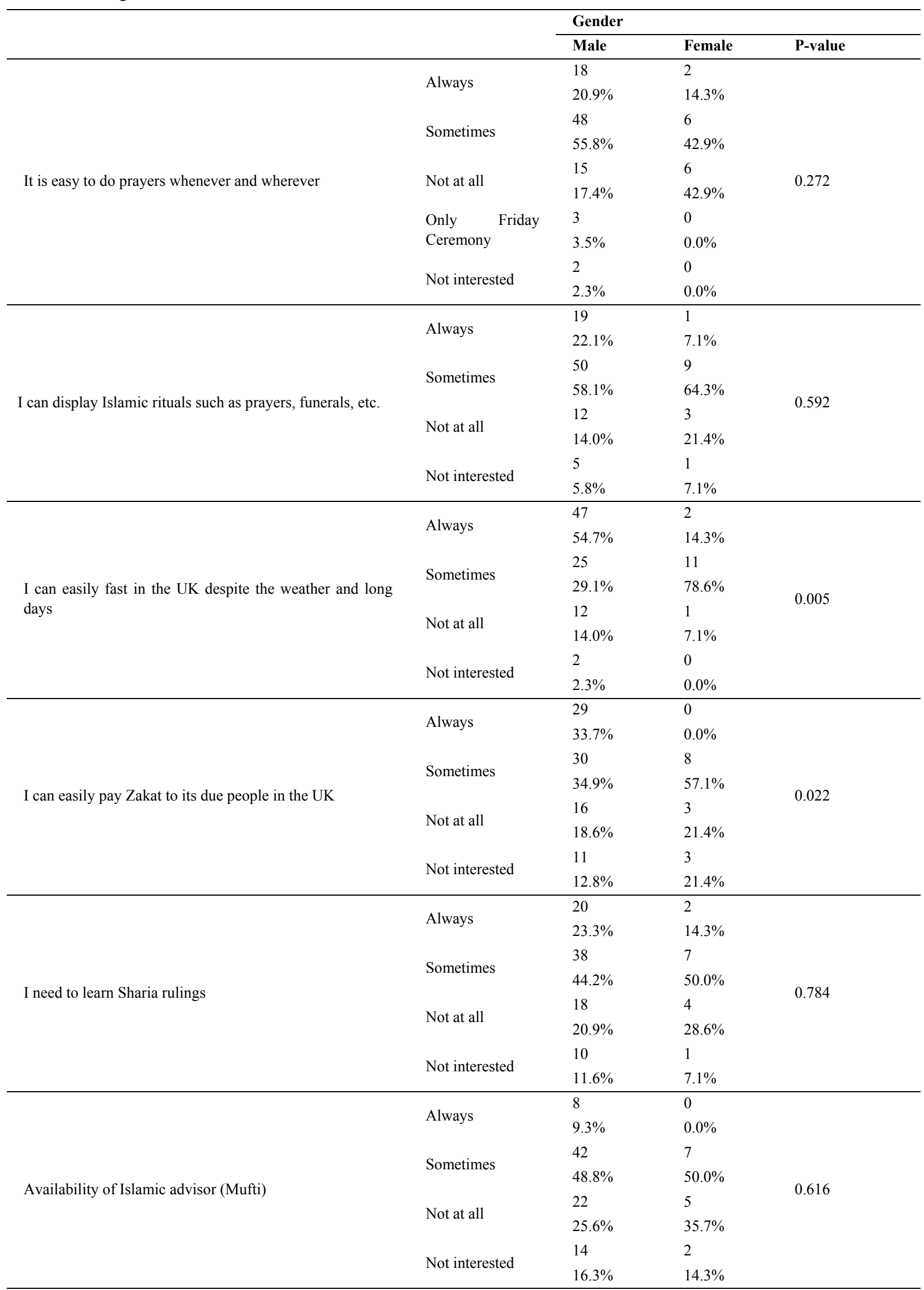


Table (3) presents the juristic challenges experienced by students in the UK. $47.1 \%$ of the male students and $64.3 \%$ of the female students faced difficulties in learning about juristic and judicial regulations in the UK. $28.2 \%$ of the male students and $21.4 \%$ of the female students faced problems in identifying the significance of civil and human rights, intellectual/religious tolerance, and women's rights. While, $54.1 \%$ of the male students agreed that academic major has a strong effect on their cultural, social, and political attitudes (Table 3).

Table 3. Juristic challenges

\begin{tabular}{|c|c|c|c|c|}
\hline & & Male & Female & P-value \\
\hline \multirow{6}{*}{$\begin{array}{l}\text { I have difficulties in learning about judicial and juristic } \\
\text { regulations in the UK: }\end{array}$} & \multirow{2}{*}{ Agree } & 40 & 9 & \multirow{6}{*}{0.220} \\
\hline & & $47.1 \%$ & $64.3 \%$ & \\
\hline & \multirow{2}{*}{ Neutral } & 31 & 5 & \\
\hline & & $36.5 \%$ & $35.7 \%$ & \\
\hline & \multirow{2}{*}{ Disagree } & 14 & 0 & \\
\hline & & $16.5 \%$ & $0.0 \%$ & \\
\hline \multirow{6}{*}{$\begin{array}{l}\text { I have a problem in knowing the significance of civil } \\
\text { and human rights, women's rights, and } \\
\text { intellectual/religious tolerance }\end{array}$} & \multirow{2}{*}{ Agree } & 23 & 4 & \multirow{6}{*}{0.866} \\
\hline & & $27.1 \%$ & $28.6 \%$ & \\
\hline & & 24 & 3 & \\
\hline & Nental & $28.2 \%$ & $21.4 \%$ & \\
\hline & \multirow{2}{*}{ Disagree } & 38 & 7 & \\
\hline & & $44.7 \%$ & $50.0 \%$ & \\
\hline \multirow{6}{*}{$\begin{array}{l}\text { Academic major has a strong effect on students' } \\
\text { cultural, social and political attitudes }\end{array}$} & \multirow{2}{*}{ Agree } & 46 & 8 & \multirow{6}{*}{0.159} \\
\hline & & $54.1 \%$ & $57.1 \%$ & \\
\hline & T & 23 & 6 & \\
\hline & Neutral & $27.1 \%$ & $42.9 \%$ & \\
\hline & \multirow{2}{*}{ Disagree } & 16 & 0 & \\
\hline & & $18.8 \%$ & $0.0 \%$ & \\
\hline \multirow{6}{*}{$\begin{array}{l}\text { Individualistic and liberalistic values have a strong } \\
\text { effect on students' cultural, social and political } \\
\text { attitudes }\end{array}$} & \multirow{2}{*}{ Agree } & 46 & 9 & \multirow{6}{*}{0.178} \\
\hline & & $54.1 \%$ & $64.3 \%$ & \\
\hline & \multirow{2}{*}{ Neutral } & 22 & 5 & \\
\hline & & $25.9 \%$ & $35.7 \%$ & \\
\hline & \multirow{2}{*}{ Disagree } & 17 & 0 & \\
\hline & & $20.0 \%$ & $0.0 \%$ & \\
\hline
\end{tabular}

Social, intellectual and cultural aspects of the challenges facing students are presented in Table (4). The majority of the neighbors of students are non-Muslims (58.0\%). Only $8 \%$ of the students faced problems with their neighbors. $18 \%$ of the students were concerned with late-night noises coming from their neighbor houses. 
Table 4. Social intellectual and cultural aspects of the challenges

\section{My neighbors}

Both are Muslims

Both are not Muslims

One is Muslim

\section{Frequency}

9

58

33

I face problems with my neighbor

$\begin{array}{ll}\text { Agree } & 8 \\ \text { Neutral } & 23\end{array}$

Disagree

Type of the problems with your neighbor

$\begin{array}{ll}\text { Loud Music } & 12 \\ \text { Noise Late Nights } & 18 \\ \text { Parties } & 10 \\ \text { Others } & 60\end{array}$

I tried to solve the problem with my neighbor

$\begin{array}{ll}\text { Agree } & 30 \\ \text { Neutral } & 55 \\ \text { Disagree } & 15\end{array}$

I'm married to

Muslim

Non-Muslim

Atheist

60.0

I face problems with my wife because of

The family
Social environment
Being away from family

In light of Sharia rulings, some challenges and problems are happening at schools

$\begin{array}{lll}\text { Agree } & 49 & 49.0 \\ \text { Neutral } & 23 & 23.0 \\ \text { Disagree } & 28 & 28.0\end{array}$

The reason for those problems happening at schools is

$\begin{array}{lll}\text { The people } & 32 & 32.0 \\ \text { The law } & 10 & 10.0 \\ \text { All of which } & 58 & 58.0\end{array}$

I tried to solve those problems

$\begin{array}{lcc}\text { Agree } & 40 & 40.0 \\ \text { Neutral } & 37 & 37.0 \\ \text { Disagree } & 23 & 23.0 \\ \text { Total } & 100 & 100.0\end{array}$

\section{Discussion}

One of the most important challenges experienced in the international setting is the students with widely 
different experiences of religious practices and backgrounds in the same classroom. Some students are easily identified with different religious practices, while rest completely lack the kind of language and experiences for what it possibly could mean to be part of religious culture. A wide variety of religious and non-religious perspectives have been characterized in some classrooms (Flensner, 2018). Religification has a complicated association with education and schooling based on a dialogic process of identification and proclamation. Schools are important platforms where Muslims may initially experience being identified as Muslims, either by their classmates or teachers. Moreover, curricula are also an essential information source where Muslimness might be portrayed as schools usually formally educate non-Muslims regarding Islam (Panjwani \& Moulin-Stożek, 2017).

Another significant challenge for Saudi students is transitioned from religious to secular practices. A Muslim faces difficulty in sustaining religious practices, i.e. praying multiple times per day on a university campus, concerns related to Halal food, and fasting in the month of Ramadan (Mcdermott-Levy 2011). The lack of institutional support hinders Muslim students' difficulty of accessing Halal food, most of the students primarily consume vegetables or snacks (Mcdermott-Levy 2011; Azhar, \& Safdar, 2016).

In the context of female Saudi students, the women face difficulty for wearing a hijab, which is indicated as a discrimination catalyst for outwardly representing religious observance. Most of the students were discriminated based on their veiling practices (Brünig, \& Fleischmann, 2015). However, Wagner et al. (2012) have pointed out that the 'veiled women' are resisting the imposition of 'liberation' and 'equality' as per the Western perspective. Instead, it is being used for asserting identity challenging the stereotypical images as well as associated assumptions.

Students contribute to the internalization and diversity of public and academic activities. For instance, these students bring various insights to issues in the classroom, appreciate the differences found in the world, and improve mutual understanding. Therefore, it is essential for accepting international students in UK universities due to their contributions to the student society on many different levels. Cultural exchange, financial income, and academic prestige are included in these levels (Baklashova \& Kazakov, 2016). An increasingly important and relevant source of diversity on college campuses is comprised of international students. they empower the cultural diversity of campuses with their ethnic experiences and home culture. Furthermore, the faculty and students are helped by international students to develop their cultural sensitivities and skills to collaborate with people from different backgrounds (Wu, Garza \& Guzman, 2015). General living adjustment, academic difficulties, personal-psychological adjustment, English-language proficiency, and socio-cultural difficulties are considered as the challenges faced by international students (bin Basri, 2015).

Middle Eastern countries are expected to continue making a strong market economy due to the rising affluence in the region, ample natural resources, and robust population growth. In particular, these regions will strive to be an attractive destination for foreign learners. The long-term economic expansion of these regions will consequently rely on successful efforts for educating and employing the increasingly expanding youth population. It is acclaimed that the doors for Muslim women have to be opened for them to join the labor force as it is likely that the number of working women will increase over the coming decade. Likewise, educational institutions will be pressurized for offering and providing a comprehensive curriculum to these women students, who may easily absorb the job environment mostly staffed by men.

\section{Conclusion}

This research explored the challenges related to rituals and law which Saudi students experience in the UK. Earlier, evidence has only been presented on the judicial and religious profiles of the language problems facing foreign students, specifically in the context of UK higher education institutes. The religious self-assessment, daily conversations, and the effects, thereof, were emphasized based on jurisdiction and law-related rituals. Saudi students with religious practices and backgrounds in the same classroom experienced some major challenges. However, Saudi students contribute to the diversity and internalization of academic and public activities. This study has revealed a variation in education policy challenges by region and cultural problems throughout the Muslim students. There is significant heterogeneity in Islamic practices of Muslims and schooling within and across the UK. The review of Islamic practices in western culture will help educators and school policymakers to consider the issues associated with UK universities. It is recommended that future research should examine the evidence in languages other than English and connect Islamic practices to education outcomes for providing policy recommendations based on the causal analysis. This study also suggests that future studies can be performed on the western countries, where local options for education, training, and professional advancement either in new institutes or within current schools can be explored. Similarly, local options will assist to provide accountability and transparency towards the state. 


\section{Acknowledgment}

The author is very thankful to all the authors whose reference material contributed to the purpose of this research. The author would also like to thank Deanship of Scientific Research at Majmaah University for supporting this work under Project Number No.1439-136 I would additionally like to thank the editorial board and reviewers for their valuable responses and fast reply.

\section{Competing Interest}

The authors declare no competing interest.

\section{Ethical approval and consent to participate}

The Majmaah University for Research Ethics Committee (MUREC) (HA-01-R-008) has reviewed the application referred to in this paper, whose ethical endeavor has been approved under Ethics Number: Oct.29/COM-2019/6

\section{Availability of data and materials}

The datasets used and analyzed during the current study are available from the corresponding author on reasonable request.

\section{References}

Alhazmi, A., \& Nyland, B. (2010, November). Saudi international students in Australia and intercultural engagement: A study of transitioning from a gender-segregated culture to a mixed-gender environment. In The 21st ISANA international education conference (pp. 1-11). ISANA International Education Association Inc.

Ali, F., Malik, A., Pereira, V., \& Al Ariss, A. (2017). A relational understanding of work-life balance of Muslim migrant women in the west: Future research agenda. The International Journal of Human Resource Management, 28(8), 1163-1181. https://doi.org/10.1080/09585192.2016.1166784

Ali, S. S. (2008). Approaches to Teaching and Learning of Islamic Law: Sharing some national and international perspectives.

Alqarni, D. S. (2018). Religion, language, gender, and culture: challenges experienced by Saudi international students in Humboldt County.

Alsabatin, H. Y. (2015). Experiences of Saudi students attending a US University: A qualitative study (Doctoral dissertation, Wichita State University).

Alshuwaikhat, H. M., \& Mohammed, I. (2017). Sustainability matters in national development visions-Evidence from Saudi Arabia's Vision for 2030. Sustainability, 9(3), 408. https://doi.org/10.3390/su9030408

Anderson, D., Wason, H., \& Southall, J. (2016). Supporting business students' transition into higher education: the case of marketing downloads. Teaching in Higher Education, 21(8), 978-989. https://doi.org/10.1080/13562517.2016.1207625

Azhar, A., \& Safdar10, T. (2016). Relationship between gender discrimination, meager family support and financial institution for women entrepreneur growth in Pashtoon and Baloch culture of Balochistan, a women entrepreneur perception. Department of Pashto University of Balochistan, Quetta. 7.

Baklashova, T. A., \& Kazakov, A. V. (2016). Challenges of International Students' Adjustment to a Higher Education Institution. International Journal of Environmental and Science Education, 11(8), 1821-1832.

Billingsley, B., Brock, R., Taber, K. S., \& Riga, F. (2016). How students view the boundaries between their science and religious education concerning the origins of life and the universe. Science education, 100(3), 459-482. https://doi.org/10.1002/sce.21213

bin Basri, B. T. R. (2015). Multicultural benefits and challenges for international students during period of their study: Case study in Malaysia. Journal of Educational, Health and Community Psychology, 4(1), 41-54.

Brünig, B., \& Fleischmann, F. (2015). Understanding the veiling of Muslim women in the Netherlands. Journal for the Scientific Study of Religion, 54(1), 20-37. https://doi.org/10.1111/jssr.12166

Chao, M. M., Takeuchi, R., \& Farh, J. L. (2017). Enhancing cultural intelligence: The roles of implicit culture beliefs and adjustment. Personnel Psychology, 70(1), 257-292. https://doi.org/10.1111/peps.12142

Dinning, T. M., Maghill, C. A., Money, J., Walsh, B., \& Nixon, S. (2016). Can a blended learning approach enhance student's transition into higher education? A study to explore perception, engagement and 
progression. International Journal of Advancement in Education and Social Science, 3(2), 1-7.

Flensner, K. (2018). Secularized and Multi-Religious Classroom Practice-Discourses and Interactions. Education Sciences, 8(3), 116. https://doi.org/10.3390/educsci8030116

Gallup, Inc. (2015, December). Perceptions of Muslims in the United States: A review. Retrieved from http://www.gallup.com/opinion/gallup/187664/perceptions-muslimsunited-states-review.aspx?g_source=per ceptions\&g_medium $=$ search\&g_campaign $=$ tiles

Heyn, M. E. (2013). Experiences of male Saudi Arabian international students in the United States. https://doi.org/10.1037/e579632013-001

Institute of International Education (2017). Open doors data. International students: Fields of study. Retrieved from https://www.iie.org/Research-and-Insights/OpenDoors/Data/International-Students/Fields-of-Study

Lefdahl-Davis, E. M., \& Perrone-McGovern, K. M. (2015). The cultural adjustment of Saudi women international students: A qualitative examination. Journal of Cross-Cultural Psychology, 46(3), 406-434. https://doi.org/10.1177/0022022114566680

Li, H., \& Suen, H. K. (2013). Detecting native language group differences at the subskills level of reading: A differential skill functioning approach. Language Testing, 30(2), 273-298. https://doi.org/10.1177/0265532212459031

Macias, T. (2016). Saudi women studying in the United States: Understanding their experiences.

McKenna, U., \& Francis, L. J. (2018). Growing up female and Muslim in the UK: an empirical enquiry into the distinctive religious and social values of young Muslims. British Journal of Religious Education, 1-14. https://doi.org/10.1080/01416200.2018.1437393

Mesidor, J. K., \& Sly, K. F. (2016). Factors That Contribute to the Adjustment of International Students. Journal of International Students, 6(1), 262-282.

NAFSA. (2017). NAFSA international student economic value tool. Retrieved from http://www.nafsa.org/Policy_and_Advocacy/Policy_Resources/Policy_Trends_and_Data/NAFSA_Internati onal_Student_Economic_Value_Tool/

Newsome, L. K., \& Cooper, P. (2016). International Students' Cultural and Social Experiences in a British University:" Such a Hard Life [It] Is Here”. Journal of International Students, 6(1), 195-215.

Panjwani, F., \& Moulin-Stożek, D. (2017). Muslims, schooling and the limits of religious identity. https://doi.org/10.1080/03054985.2017.1354585

Perna, L. W., Orosz, K., Gopaul, B., Jumakulov, Z., Ashirbekov, A., \& Kishkentayeva, M. (2014). Promoting human capital development: A typology of international scholarship programs in higher education. Educational Researcher, 43(2), 63-73. https://doi.org/10.3102/0013189X14521863

Pilkington, H. (2018). Countering Radicalisation: Rethinking the role of communities. Retrieved from https://www.britsoc.co.uk/about/latest-news/2018/july/countering-radicalisation-rethinking-the-role-of-com munities/

Powell, K. (2018). Framing Islam/Creating Fear: An Analysis of US Media Coverage of Terrorism from 20112016. Religions, 9(9), 257. https://doi.org/10.3390/rel9090257

Saigh, K., \& Schmitt, N. (2012). Difficulties with vocabulary word form: The case of Arabic ESL learners. System, 40(1), 24-36. https://doi.org/10.1016/j.system.2012.01.005

Simbar, R. (2008). The changing role of Islam in international relations. Journal of International and Area Studies, 55-68.

Smith, T. B., \& Silva, L. (2011). Ethnic identity and personal well-being of people of color: A meta-analysis. Journal of Counseling Psychology, 58(1), 42. https://doi.org/10.1037/a0021528

Statista. (2016). Estimated Muslim populations in European countries as of 2016. Retrieved from https://www.statista.com/statistics/868409/muslim-populations-in-european-countries/

Statista. (2019). Number of racially motivated hate crimes in England and Wales from April 2017 to March 2018, by region. Retrieved from https://www.statista.com/statistics/623394/racial-hate-crimes-in-england-and-wales/

Stevenson, J., Demack, S., Stiell, B., Abdi, M., Clarkson, L., Ghaffar, F., \& Hassan, S. (2017). The social 
mobility challenges faced by young Muslims. September 2017.

UK International Students Affair Council (2018). International student statistics: the UK higher education. Retrieved from https://www.ukcisa.org.uk/Research--Policy/Statistics/International-student-statistics-UK-higher-education
UNESCO
(2016).
Education;
Higher
Education.
Retrieved
from $\mathrm{http} / /$ www.unesco.org/new/en/education/themes/strengthening-educationsystems/higher-education/

Wagner, W., Sen, R., Permanadeli, R., \& Howarth, C. S. (2012). The veil and Muslim women's identity: Cultural pressures and resistance to stereotyping. Culture \& Psychology, 18(4), 521-541. https://doi.org/10.1177/1354067X12456713

Wu, H. P., Garza, E., \& Guzman, N. (2015). International student's challenge and adjustment to college. Education Research International, 2015. https://doi.org/10.1155/2015/202753

Yakaboski, T., Perez-Velez, K., \& Almutairi, Y. (2016). Collectivists' decision-making: Saudi Arabian graduate students' study abroad choices. Journal of International Students, 7(1), 94-112. https://doi.org/10.32674/jis.v7i1.247

\section{Copyrights}

Copyright for this article is retained by the author(s), with first publication rights granted to the journal.

This is an open-access article distributed under the terms and conditions of the Creative Commons Attribution license (http://creativecommons.org/licenses/by/4.0/). 